This item was submitted to Loughborough's Research Repository by the author.

Items in Figshare are protected by copyright, with all rights reserved, unless otherwise indicated.

\title{
An evaluation of the retrospective accounts of offenders as a means to promote desistance amongst acquisitive offenders
}

PLEASE CITE THE PUBLISHED VERSION

https://doi.org/10.1080/10509674.2019.1615597

\section{PUBLISHER}

(C) Taylor \& Francis (Routledge)

\section{VERSION}

AM (Accepted Manuscript)

\section{PUBLISHER STATEMENT}

This is an Accepted Manuscript of an article published by Taylor \& Francis in Journal of Offender Rehabilitation on 26 Jun 2019, available online: https://doi.org/10.1080/10509674.2019.1615597

\section{LICENCE}

CC BY-NC-ND 4.0

\section{REPOSITORY RECORD}

Quinn, Anthony, and Louise Cooke. 2019. "An Evaluation of the Retrospective Accounts of Offenders as a Means to Promote Desistance Amongst Acquisitive Offenders”. Loughborough University.

https://hdl.handle.net/2134/35104. 
Title: An evaluation of the retrospective accounts of offenders as a means to promote desistance amongst acquisitive offenders.

Anthony Quinn and Louise Cooke

\begin{abstract}
:
There are various considerations which former offenders give for ceasing to commit offences. These involve references to more mature decision-making, reformed ways of regarding the victim and realisations that risks of offending outweigh the rewards. This study draws upon twenty semi-structured and visually-based qualitative interviews with probationers to examine the role that these factors played in engendering desistance from acts of acquisitive crime. A tailored evaluation of desistance does not appear to have been undertaken. The outcome of these findings and how, in the future, they could facilitate the supervision of individuals on probation is critically discussed.
\end{abstract}

Keywords:

offender rehabilitation, probationers, probation outcomes, desistance, qualitative research

Words: 6889

Acknowledgements:

The authors would like to thank Her Majesty's Prison and Probation Service (UK) and the Derbyshire Leicestershire, Nottinghamshire and Rutland Community Rehabilitation (UK) for their facilitation of this research study. 


\section{Introduction}

Individuals who have previously committed offences and are regretful of their actions constitute a useful source to learn from, since their perspectives on offending might assist in deterring other similar-minded individuals (Gill, 2017). This has been somewhat realised within probation services in England and Wales with the establishment of Peer Mentoring schemes (see DLNR CRC, 2014a). Within these schemes, former offenders, who have undertaken training on how to act as a positive role model, offer advice and motivation to service users fulfilling a probation order (DLNR CRC, 2014a). Whilst examples of how learning from offenders can lead to the improved implementation of crime prevention measures (see Ekblom, 1995; Ekblom, 1997; Gill, 2017; Jacques and Bonomo, 2017) through initiatives like Peer Mentoring schemes, the retrospective accounts of offenders can also be valuable for encouraging desistance. Adopting a deviant identity and the associated thought processes can influence future recidivism (Crank, 2018), so a crucial task might be to understand, challenge and offer alternatives to perspectives that entertain offending behaviour. Previous literature has engaged with reasons why offenders might give up offending lifestyles (Farrall, 2016) but not with the retrospective accounts of offenders and how these could be tailored to similar others seeking to desist from acts of acquisitive crime.

In the UK, under the accreditation of Her Majesty's Prison and Probation Service, there are behaviour programmes for offenders which address various types of offending behaviour (Justice, 2017). Examples of these include: Addressing Substance Related Offending (Justice, 2017), the Building Better Relationships Programme for male perpetrators of domestic violence (Hughes, 2017) and the Thinking Skills Programme (TSP) which addresses the way offenders think (Justice, 2017). Whilst addiction to illegal drugs has consistently been viewed to play a role in a significant deal of acquisitive crime such as burglary or vehicle crime (see Parker and Newcombe, 1987; Stewart et al. 2000; Holloway et al. 2004; Ceccato, 2009), there seems to have been less coverage of the thought processes, decision-making and effective triggers of desistance for this type of offender. The benefits of a TSP programme (Justice, 2017) are therefore somewhat under-appreciated. This article assesses qualitative insight from individuals who have committed acquisitive crime offences and evaluates prominent themes which emerged amongst these perspectives. This could inform improved guidance. Possible reasons for desistance, as featured within the work of Farrall (2016), are 
utilised as a framework. These address: how age and perceptions of self-maturing impact on offending decisions, how a consideration of victims can facilitate desistance and the importance of challenging offender calculations within an offending context (Farrall, 2016).

Research in the USA has reported that, within a similar scheme to Peer Mentoring Schemes in the UK, "mentors discussed a variety of issues and problems with their mentees. Substance abuse and addiction were major problems faced by many mentees'” (Stacer and Roberts, 2018: 15). Two further issues that were commonly faced involved problems with housing and employment (Stacer and Roberts, 2018). As well as guidance being offered on these important issues, there might also be other significant considerations that could be used to rehabilitate offenders into a changed way of thinking. Schaefer (2017) has reported the utility of challenging offending identities by using cognitive behavioural techniques and promoting identity substitutions. This article seeks to examine these measures more closely and to envisage what these might consist of for a particular crime type. If suitable empathy is shown toward the situation of the service user (a name given to individuals sentenced to a community order in England and Wales) and the appropriate guidance is given, this could serve as a significant factor in the continuation decision (Paternoster, 1989). Essentially, this is the decision which faces former offenders of whether to reoffend (Paternoster, 1989). At least from an academic perspective, a review of this decision for acquisitive crime appears undocumented.

The importance of insight and tailored interventions for acquisitive crime (or what is termed in the USA as property crime) stems from its label as a high-volume crime (Ratcliffe, 2009). In England and Wales, between July 2016 and June 2017, over 1.3 million acquisitive crime offences were recorded by the police, of which 427, 561 were cases of vehicle crime offences (ONS, 2017); this constitutes nearly a third of all acquisitive crime. In the USA, vehicle theft refers to the theft or attempted theft of a motor vehicle (FBI: UCR, 2010a) whereas in the UK, vehicle offences refer to Aggravated Vehicle Taking, Theft from a Motor Vehicle, Theft or Unauthorised Taking of a Motor Vehicle and Interfering with a Motor Vehicle (Home Office, 2018). In the UK, the category for vehicle crime is broader than it is in the USA predominantly because it includes Theft from a Motor Vehicle which in the USA would be classed as a larceny-theft (FBI: UCR, 2010b). Given the extent to which this crime type is recorded, its effective reduction could assist in transforming the lives of offenders and this in turn could have a significant impact on the amount of vehicle crime that is experienced. 
The subjects of this study might have committed other offences, but it was only reflections on one or more of these vehicle crime offence categories that were the focus. Information contained within these accounts could prove to be a valuable tool when it comes to supporting service users with similar profiles, backgrounds and involvement in vehicle crime offences (and perhaps acquisitive crime more generally). Vehicle crime might not be identical to other types of acquisitve crime but there are strong parallels with regards to why vehicle crime and acquisitive crime (more generally) is experienced and who it is committed by (see Parker and Newcombe, 1987; Holloway et al. 2004; Ceccato, 2009; Felson and Boba, 2010; Farrell et al. 2011; Tilley et al. 2015). In addition, the focus upon a specific type of crime constitutes a novel approach because studies on probation and offender rehabilitation have tended to examine offenders more broadly without perhaps unpacking specific details about why a specific offence was continually committed in the first place.

This article discusses some retrospective accounts about an acquisitive crime type and evaluates how they might be of benefit for the future supervision of service users.

Furthermore, in order to demonstrate that not all service users provided positive reflections of their probation experiences, some opposing narratives are provided. This article begins by offering a review of relevant literature before detailing the context of the study and the methodology which was used to obtain this qualitative insight. In particular, the unique worth of undertaking offender-based research is made clear. This is followed by an engagement with qualitative findings before conclusions to be drawn from the study are given. Lastly, some ideas for future study of offender rehabilitation are given.

\section{Theoretical Context}

Reasons which offenders give for ceasing to engage in offending behaviour have been explored by Farrall (2016). Some leave behind an offending lifestyle because they simply 'grow out of it', as they find more rewarding pursuits, or because the risks of offending eventually become too great (Farrall, 2016). The latter reason bears resonance with the Rational Choice Theory put forward by Cornish and Clarke (2014) and with the finding of Paternoster (1989) that the offender repeatedly makes active decisions to offend based upon an assessment of forthcoming detection and sanctions. This has been supported by Shover 
and Thompson (1992) who recognise that an offender is unlikely to desist if they perceive success to be a distinct possibility and if they have not experienced failure in this task. Other explanations why an individual might cease to offend include getting to a certain age or reaching a stage when those who are negatively impacted by the offence can no longer be overlooked (Farrall, 2016). These are reasons why an individual who has offended might stop committing further offences and here insight is offered into how offenders reflect upon this stage in their life after they have successfully desisted.

It has been stated that 'while there is no agreed theoretical or operational definition of desistance, most criminologists have associated desistance with both ceasing and refraining from offending' (Weaver and McNeil, 2011: 37); although this is not necessarily a clear-cut transition (Weaver and McNeil, 2011). Furthermore, there are two types of desistance termed 'primary’ and 'secondary desistance’ (Marunna and Farrall, 2004). 'Primary desistance’ describes a pause in offending during an offending career whilst 'secondary desistance' refers to a complete stop in offending as a result of the individual distancing themselves from a former lifestyle, character or group (Marunna and Farrall, 2004). This is important for the current study because there can be no assurance of whether the participants who took part in the study can be classed as fitting either the 'primary' or 'secondary desistance' category (Marunna and Farrall, 2004); there was likely to be a mixture of both types in the sample since some might have been re-offending at the time when the research interviews were conducted (away from the attentions of law enforcement agencies) and some might have reoffended afterwards.

On the topics of lifestyles, group membership (Marunna and Farrell, 2004) and the study of why offenders might continually operate in particular places, Weisburd et al. (2016) address the possibility that offenders exchange knowledge about how and where to take advantage of victims. This is deemed more likely to occur in areas where much victimisation has already taken place (Weisburd, et al. 2016). For successful rehabilitation of the individual, it is likely essential to work towards avoidance of these areas and the severance of ties with individuals who request and provide this information; these could perhaps be replaced with pro-social ties (Hepburn and Griffin, 2004). Research has shown that "the social bond had a significant effect on sustaining probation success over time’” (Hepburn and Griffin, 2004: 69). This latter point fits with the popular social control theory (Gottfredson and Hirschi, 1990: Hirschi and Gottfredson, 2017) and how the likelihood of an individual committing criminal acts 
depends on their bond to society. Imperative is whether there are parties who can act as a social restraint for the individual and who can help to outweigh temptations to offend (Gottfredson and Hirschi, 1990; Hirschi and Gottfredson, 2017). This is especially relevant for acquisitive offenders where it has been found that accomplices are often sought out before the commission of burglary, robbery and vehicle crime offences (Shover, 1973; Maguire and Bennett, 1982; Walsh, 1986; Weerman, 2003; NAO, 2007). Temptations of offending might equally apply for more modern offences like cyber-crime where the influence of co-offenders has also been documented (Meyer, 1989; Chantler, 1995; Hutchings, 2014).

Supervision of service users by CRC practitioners has been described as meaningful and desistance-focused (Kay, 2016) as part of an overall mission to transform lives (DLNR CRC, 2014b). This conceivably involves a transformation in cognitive decision-making (Schaefer, 2017) by the service user which means that they will perhaps refer to offending decisions differently from how they might have done at the time of offending. The reasons for cessation, proposed by Farrall (2016), are likely to somewhat shape this, and the process of reintegrative shaming whereby the offender(s) comes to realise their guilt and the detriment of the victim(s) (Braithwaite, 1989).

At this juncture, it also needs to be expressed that individuals on probation do not constitute a homogeneous group and therefore some might respond differently to certain interventions; to encourage improved decision-making and lifestyle choices amongst minority ethnic offenders, an appreciation of how their self-identity differs might be required (Williams, 2006) as well as a recognition of their particular needs and experiences (Lewis, 2006). Within another branch of the criminal justice system (but one that service users are likely to have passed through), Stoneman et al. (2018) have documented that service users present with an array of complex mental and emotional needs; how well these needs are addressed is likely to impact upon the desistance process as well. Age and sexuality are other factors that might demand slightly different desistance-focused efforts. Moreover, references to personal experiences by prolific offenders, who have repeatedly engaged with assessments of whether and how to offend (Paternoster, 1989; Cornish and Clarke, 2014), are likely to differ from those who committed one or few offences. Given that prolific offenders, or those who have committed six or more offences, have been seen to commit over ten times more theft offences than non-prolific offenders (Hopkins and Wickson, 2012), targeting the retrospective views 
of prolific offenders could provide a better understanding of attitudes or circumstances that influenced continued offending.

The reflections of service users upon the role probation services had on their offending have been mixed. In one study, service users stated that probation services instilled them with confidence to desist from crime and provided instruction on how to improve decision-making skills (King, 2013). As King (2013) points out, this is an improvement which bears resonance with the Rational Choice Theory (Cornish and Clarke, 2014) since the assessment of detection and negative aspects of offending ideally take on increased significance upon fulfilment of a probation order. On the other hand, Weaver and McNeil (2011) cite a study in New Zealand where those on probation gave several reasons that helped with desistance but fewer than half mentioned that these were related to experiences of probation. To facilitate effective support to service users, a recommendation has been that probation work should pay close attention to the personal and social contexts of service users (King, 2013). This has had positive effects, for example, on familial relationships and employment prospects, which are key factors in desistance (Farrall, 2002); another important issue is housing (Stacer and Roberts, 2018). The ability to make effective lifestyle decisions however has been deemed even more important for desistance than personal or social contexts (King, 2013). An understanding of the retrospective accounts of those who have committed similar offences, and how their perspectives have altered their decision-making processes, might facilitate desistance-orientated guidance in the future.

In this article, references to the perceived assistance of probation and key factors for desistance are explored. It is not suggested that these retrospective accounts will definitely hold for individuals who have committed other crime types but this is a distinct possibility since some forms of vehicle crime tend to be committed by 'generalists' rather than those who specialise only in the commission of vehicle crime (NAO, 2007). Furthermore, they offer valuable perspectives on acquisitive crime that have not been previously investigated in terms of why offenders might desist from such activity; learning about offending should not only involve examining the immediate situation where offences were committed (Elffers, 2011). 


\section{Methods for the Study}

Obtaining the retrospective accounts of offenders involved conducting qualitative one-to-one interviews with service users. These service users were recruited through the Derbyshire, Leicestershire, Nottinghamshire \& Rutland Community Rehabilitation Company (The DLNR CRC) as part of a wider study into contextual influences of decisions to commit vehicle crime offences. This organisation is situated in England and serves the neighbouring counties of the East Midlands (see The DLNR CRC, 2014). The main probation hubs of the DLNR CRC are situated in the cities of Leicester, Nottingham and Derby whilst there are smaller regional offices that serve more rural areas. The DLNR CRC works under Her Majesty's Prison and Probation Service and alongside the National Probation Service of England and Wales to supervise individuals who have received court sentences (see Gov.uk, nd).

To explore more closely “offenders' accounts of their own actions, cognitions and emotions"' (Elffers, 2011: 14) and how this might inform the promotion of rehabilitation and reintegration (Schaefer, 2017) in the future, twenty participants were recruited. The research study was granted full ethical approval by Loughborough University and approved by the National Offender Management Service (now called Her Majesty’s Prison and Probation Service). In accordance with these ethical stipulations, all interviews took place on DLNR CRC premises and to adhere to fundamental ethical principles (Noaks and Wincup, 2004). Polišenská (2010) has considered the questionable validity of empirical responses which are obtained within criminal justice facilities, yet ethical stipulations do not tend to permit meeting offenders in public spaces. Conducting research within criminal justice facilities is therefore the most suitable avenue for obtaining the accounts (which would otherwise go undocumented) of members of the population who are regarded as vulnerable. Information sheets were distributed to all gatekeepers and participants; the latter were also required to sign informed consent forms prior to participation. These explained to participants that all content from the interviews would be kept confidential and would remain anonymous. As a result, pseudonyms are used for all documentation of these responses. Consent forms specified that interviews would be recorded using an audio recording device and that the recordings would be kept in a secure and password protected location for ten years after completion of the project. This is in line with the ethical stipulations of the university that authorised the research (see Loughborough University, nd). The interview manuscripts were 
coded and analysed using the qualitative data analysis software Nvivo 10 and a thematic analysis (Bryman, 2016) was opted for, since the themes of desistance, probation and signs of rehabilitation were of primary interest.

Those who might have served as suitable interview candidates were briefed and put forward by probation practitioners. In this respect, probation practitioners acted as gatekeepers or points of access (Bryman, 2016) for the study. It could be stated that the selection of interviewees by practitioners might have influenced a delivery of overly positive views however participants were assured that no information could be shared with practitioners (unless it related to safeguarding or undetected offences) and that the interviewer was a researcher who was external to any probation organisation. Within the interviews, participants were asked to review contexts that might be vulnerable to vehicle crime victimisation and to explain their impressions. Importantly, no participants were asked to give retrospective accounts of their offending or to reflect upon instances when they had offended since "forcing people to give answers on motivation questions may well force them to return answers that have only a feeble relation to reality', (Elffers, 2011: 16). As recommended by Elffers (2016), the interview process was steered towards hypothetical situations in which vehicle crime offences could occur. This was carried out through the use of visual stimuli (see Bennet and Wright, 1984; Nee and Taylor, 2000; Nee and Meenaghan, 2006; Nee, 2011), in the form of snapshots which depicted locations potentially vulnerable to vehicle crime (see Quinn and Grove, 2018), followed by open-ended and non-judgemental questions (Ritchie et al. 2014). Subsequently, participants sometimes reflected upon times when they had offended. In effect, the decision by participants to divulge these accounts was completely of their own choosing; it is these descriptions that comprise the findings and analysis of the next section.

Although no assertion is made here that this is an incontestable banding, nine of the interviewees fitted what Hopkins and Wickson (2012) have termed as a 'prolific offender' (an individual who has committed more than six offences), whilst eleven of the participants can be classed as 'non-prolific' (since they had committed fewer than six offences). It should be noted however that the number of 'prolific offenders' in this sample is likely to be greater for two reasons. Firstly, ethical stipulations stated that during the interview, participants were only allowed to disclose offences for which they had received criminal convictions. This means that the number of offences committed by participants (and not detected thus resulting 
in a criminal conviction) is potentially much higher. Secondly, the study involved only the examination of vehicle crime offences so whilst 11 participants can be classed as non-prolific offenders (Hopkins and Wickson, 2012) for this crime type, they could have committed offences for other crime types which means they could be labelled 'prolific offenders' (Hopkins and Wickson, 2012) more generally.

Before moving to discuss the findings of this study, it is necessary to contemplate some of the limitations encountered when only utilising offenders as a source of data. Elffers (2011) considers the importance of misinformation, misunderstanding and misleading when communicating with offenders about offending. He questions: 'to what degree can we interpret offenders' statements on their behaviour as a true representation of what has happened in the past, around the time they contemplated and actually committed an offence?' (Elffers, 2011: 13). Whilst this is a valid question that highlights some instances when members of an offender sample might offer inaccurate accounts of past events, although other records might be used to support this recall (Brookman, 2011), there appears no better option than engagement with perpetrators of these actions. It could be stated that individuals who have broken the law cannot provide a reliable knowledge because they will not want to share insight into how to offend successfully (Jacques and Bonomo, 2017). However, if they are undergoing rehabilitation, have ceased offending and have less incentive to commit acts of crime then there seems good reason why they may reflect honestly upon their past. It is taken on trust that participants had ceased offending but if they had not then their accounts could be labelled as disingenuous and an unfair reflection. This has been termed as a 'blind spot' (Farrall, 2016) when undertaking research of this nature because one can never be certain that an individual has completely ceased offending. By the same token, this type of research with an offender sample would not be possible if this limitation was looked upon as a constraint rather than a consideration. 


\section{Findings}

\section{$\underline{\text { Reaching a certain age (Farrall, 2016) }}$}

The most prominent theme to emerge from the accounts of participants, when mentioning why they no longer found appeal in committing vehicle crime offences, was age and how that altered their perspective. This was exemplified by the responses of Wilson and Darryl. Their references to age were made after being asked rather different questions about the nature of the vehicle offences they had committed. When asked whether the commission of one vehicle crime (for example Theft from a Motor Vehicle) tends to lead to the commission of another (for example Theft of a Motor Vehicle) promptly afterwards, Wilson implied that committing offences in quick succession was something the young and unwise might contemplate (the age of participants at the time of interview are displayed after their name):

Wilson (42): well one thing could probably lead to the next thing, yeah... I don't know really; like I say, I'm a bit older and wiser now than I used to be. I wouldn't go and do that type of thing. I wouldn't even contemplate it now.

It was discussion around whether peers collude in the commission of vehicle crime offences that led Darryl to mention how peer pressure had been a factor in some of the offences he had committed. Age was important in this context because being younger was associated with being more susceptible to acting on impulse when in the company of peers:

Darryl (33): Certainly as I got older, and more in control of... of what decisions I made... I was... I was perhaps encouraged to do stuff like that again but never really y'know, decided to make that decision to.

Emphasis of risk calculation (Cornish and Clarke (2014), might have a significant role to play in helping with desistance, but a change in age appears to be significant of itself. It appeared to be a key factor in helping participants to turn their backs on offending since it was perceived as an activity that would only be expected of younger, more care-free generations: 
Phil (44): We were young. The law was as simple as this... the... the law could do its worst if it wanted to. Now in reality, I get caught stealing the car now, I'll get me arse kicked.

This aligns with the discussed control theory (Gottfredson and Hirschi, 1990; Hirschi and Gottfredson, 2017) and how attachment to individuals with pro-offending thought processes can influence disaffection to society and its laws. From this, the key to deterrence would appear to involve a conveyance of the seriousness of a court sentence and the need to resist offending groups that might normalise offending. This is particularly likely to apply for vehicle crime offences since the average age of onset of theft from a motor vehicle is between 12 and 14 years (NAO, 2007) and three quarters of those convicted of either theft of or from a vehicle will have received a conviction for another crime type (NAO, 2007). These offender extracts do not include any reference to Probation and the services provided so it is not possible to gage any influence they had on these self-realisations regarding age and outlook on offending. A clear point to recognise though is that with increased age, service users seemed to suggest that there were fewer justifiable excuses to commit offences.

\section{Growing out of it (Farrall, 2016)}

Closely related to age were notions of offending as part of a mind-set from which participants were trying to move away. Although some participants demonstrated that knowledge of how to commit vehicle crime stayed with them, they seemed to distance themselves from it by mentioning that with time they were trying to think differently in situations where there was discernible opportunity. When asked if he used to possess a knowledge of contexts particularly vulnerable to vehicle crime, Brendan recalled that he had been exposed to one but that it no longer served as a temptation:

Brendan (24): But I left it. I walked past it but I know if I'd have just had a look, I would have found something in there but y'know what I mean... I'm trynna change my ways.

Colin and Wilson offered similar views when asked if they could identify ideal circumstances for vehicle crime to occur. Changed thought processes were cited as a key reason why an opportunity would no longer offer any appeal to them:

Colin (35): my mind doesn't work like that anymore coz that'd get me in trouble. 
Wilson (42): I suppose I think different to how I used to as well though.

In each of these three instances, there are references to change that seemed to shape the way participants responded to temptations about potentially vulnerable contexts. Here the relevance of challenging offender cognitions as part of a rehabilitation process (Schaefer, 2017) is pertinent. Helping to improve decision-making skills in particular situations (King, 2013) would appear to have a positive impact upon resultant actions and behaviours.

Once more, the risk calculation that might have been exercised at a time when participants were more inclined to offend (Paternoster, 1989; Cornish and Clarke, 2014) appears to be a process that participants were reluctant to engage in. As was the case with the age of the offender, discussion of vehicle crime involved recalling a way of thinking that only a former self would have entertained. This might be representative of secondary desistance (Marunna and Farrall, 2004) amongst these participants whereby offending behaviour has been successfully discontinued. On the other hand, it is possible to slightly overstate this due to the fact that interviews took place within a probation environment. In what capacity this change in perspective is attributable to the services provided by probation could be inspected more closely. The utilisation of a structured interview or a self-administered questionnaire (Bryman, 2016) constitute two possible avenues. Nonetheless, the data collected from this sample suggests that continued encouragement to reshape thinking in this fashion could be an effective approach.

Those negatively impacted by the offence can no longer be overlooked (Farrall, 2016)

A part of the research interview probed if there were crime preventions measures that might have facilitated desistance for the participant. Amongst some, this triggered discussion of increased empathy with those affected by their offending rather than deterrent measures that had been effective. Again, the sample suggested that a changed thinking about offending had a key role to play in curtailing a criminal lifestyle:

Bianca (20): like... the offending lifestyle was just... like at first I liked it; like I weren't bothered... like I just... I just didn't care at all but then I started to think about it and I think about like, the impact it had on other people ermm... and I just wanted to stop offending. 
Brendan (24): like... I went to [place name], it's nothing to be proud of but it's like... looking back on it, it's like... it's funny.

Interviewer: yeah?

Brendan: but it's not. It's not because people had like lost something. I feel bad about it now.

Despite the fact the sincerity of these accounts cannot be proved, they possibly demonstrate evidence of secondary desistance (Marunna and Farrall, 2004) since consideration of victims provides some evidence that offending behaviour might have been discontinued. This is resonant with a possible positive impact that reintegrative shaming can produce whereby the offender(s) is educated about the negative effect of their actions as part of their rehabilitation (Braithwaite, 1989). Although only one indicator of a successful transition from an offending lifestyle (Weaver and McNeil, 2011), a greater regard for victims is likely to be a factor that decreases propensity to make rational decisions to offend (Cornish and Clarke, 2014). When retrospectively considering how they had behaved, participants implied that a selfish disregard led to little or no concern with how stealing a vehicle would impact upon the owner(s):

Craig (33): the vehicle's not cost you nothin', I know it's $c^{* * * i s h}$ and obviously somebody's taking a loss but in them times, I didn't see it like that. It was all me, me, me, me, me.

Bianca (20): I just didn't think about anything like that. Like I weren't thinking about anybody other than myself and I just... I just didn't care. Like I weren't bothered at all.

If an evaluation of how victims are negatively impacted by offences is part of the rehabilitative efforts of CRCs, then it appears to have had some positive outcomes on the sample that were interviewed. A consideration of the effect upon victims served to counterbalance self-interested motivations that initially instigated offending behaviour. An approach that harnesses this way of thinking might be useful with others who share similar traits. 
The risk of offending becomes too great (Farrall, 2016)

This final section focuses on the assessment of risk that takes place when deciding whether to commit offences (Paternoster, 1989; Cornish and Clarke, 2014) and how the risk of offending (Farrall, 2016) was a substantial reason why the commission of vehicle crime offences became unattractive. Out of the four explanations presented here, this most closely represents discussion of the immediate situation where offences were committed (Elffers, 2011) in contrast with wider sentiments experienced when offending. Perspectives here tended to centre upon the prospect of eventually being caught and ending up in prison rather than the effectiveness of any particular crime prevention measure. Interestingly, it did not appear to be the overriding threat of being apprehended for committing one offence that acted as a deterrent but rather a perception that committing several offences would increase this prospect. This was summed up by the recollections of Dwayne and Bianca:

Dwayne (33): I've messed up a lot of choices but it's not the way forward. It's definitely not. It's not err... it's just not sustainable.

Bianca (20): then after the second time, like I very nearly went prison, ermm it just... I dunno, it was like a wake-up call. And I just thought like the impact it was having on other people... and I just thought I can't keep doing this. I'll end up in prison.

From the accounts given, one reason the commission of offences seemed more likely at a younger age was because it appeared to be a stage when the repercussions of offending had not been fully contemplated or understood. Whilst it might have appeared possible to commit one offence without detection, the risk of apprehension was perceived to increase with each offence committed. Experience of a prison sentence or another form of punishment might also have caused the potential risk of offending to become greater for these participants.

An assessment of perceived risk versus reward (Cornish and Clarke, 2014) seems to be an effective point of reflection for CRC staff to engage in with service users. This is likely to be the case because service users on probation have already received one conviction and so have experience of weighing up risk (albeit unsuccessfully). This is not to suggest that receiving a conviction will serve as a deterrent to all service users but for some it proved to be a significant reason why committing vehicle crime offences was something to refrain from. 
There are other crime reduction agencies with a significant role to play in communicating risk to potential or past offenders, but this is one approach that might increase the likelihood of desistance amongst those who have committed vehicle crime offences and possibly other acquisitive crimes. Gill (2016) reviews what have been termed as forms of enhanced probation as part of a strategy of 'focused deterrence'. Within such a programme, probation officers maintain closer contact with service users and other agencies in a bid to prevent reoffending (Gill, 2016). This is an avenue which could be pursued further and could present probation practitioners with a chance to reinforce the risk of offending whether through reference to heightened police operations in an area or more severe sanctions (Gill, 2016).

\section{Counter narratives to the accomplishments of probation}

As stated earlier, when they were asked, some who experience probation licenses are reticent about their experience or do not express that their supervision resulted in any particularly positive outcomes (see Weaver and McNeil, 2011). In order to demonstrate that not all within this interview sample regarded guidance by probation in a positive light, opposing accounts are now offered. Upon discussion of deviant peers and the role they had played in this individual's involvement in stolen vehicles, the following comment was made:

Interviewer: (during your time on probation) has anything been done to stop you being led in (to a criminal lifestyle) again?

Alex (37): oh no. No, they don't do things like that.

Despite the availability of rehabilitative programmes, such as a Thinking Skills Programme (Justice, 2017) that is tailored towards improving pro-social decisions when faced with criminal stimuli, Alex was adamant that such guidance had not been available. Within a framework of promoting desistance amongst service users, this short extract conveys how rehabilitative programmes might not be offered, or perhaps not suitable, to all. Elsewhere, another participant was clear that he felt remorse for his offending after the incident(s) and because of rehabilitative efforts which had come later in prison (but before his probation license): 
Mark (29): seriously! After when we've done it [offended]... we don't think.... that's why we do these courses in jail called thinking skills and that. So, it's literally to try and get people to think before they act.

Interviewer: yeah?

Mark: people know... it's like me... I think after I've acted so I do regret what I've done. I don't regret for what I've done at the time.

This does not necessarily suggest that rehabilitative programmes should begin prior to a custodial sentence but rather that, by the time some individuals end up undertaking a probation license, they have engaged with desistance orientated reflection and perhaps would not benefit from more. When this is the case, attention could be focused solely on other issues such as possible drug addiction and problems finding housing and employment (Stacer and Roberts, 2018). Probation practitioners are likely to be best placed to judge what course of action will be most beneficial. It is therefore imperative that practitioners are given sufficient time to understand the profiles of service users so as to avoid averting rehabilitative work when it would be of use and mismanagement of resources when it would not be.

\section{Discussion and Conclusion}

Various reasons why individuals appeared to cease committing vehicle crime offences have been discussed and they bear resonance with previous findings (Farrall, 2016) for desistance more generally, irrespective of crime type. One of the four key reasons explored here included mention of increased risk whilst offending; the remainder related to changed perspectives and consideration of the victims of offences. Desistance seemed to be closely linked to an understanding that committing acquisitive offences was not a sustainable career choice or an attractive one, alongside a perception of increased risk when committing offences. A consideration of 'blind spots' (Farrall, 2016) and the limitations of examining desistance amongst offenders also needs to be reiterated. The exact parameters which need to be met for an offender to be labelled a 'desister' can be debated (Weaver and McNeil, 2011; Farrall, 2016) and there are limitations of collecting data from this source (Farrall, 2016) however these can be offset through analysis of other records (Brookman, 2011, Farrall, 2016) for example, police arrest data (Farrall, 2016). 
There are a number of points that emanate from the analysis of these findings relating to desistance. Firstly, in England and Wales, a Thinking Skills Programme (TSP) for adult offenders (Justice, 2017) which addresses decision-making appears well-placed. This is supported by almost all the participants within this sample who made reference to a changed way of thinking since the period in their lives when they had been offending. A different outlook was central to their ability, or at least desire, to desist from offending. Given the similarities of some of these responses, programmes could be more closely tailored to particular offender groups and specific scenarios. Here, it was individuals who had committed vehicle crime offences who were the subject of study and they are somewhat comparable to perpetrators of other acquisitive crimes such as burglary and robbery (see Shover, 1973; Maguire and Bennett, 1982; Walsh, 1986; Parker and Newcombe, 1987; Stewart et al. 2000; Weerman, 2003; Holloway et al. 2004; Ceccato, 2009). As was stated in the introduction, vehicle crime offences alone are recorded in a large volume (see ONS, 2017) so tailoring sessions more closely to the requirements of this offender population could be beneficial for both them and the reduction of a significant deal of recorded crime. This article unpacked four explanations which could be central for successful desistance, but these could be supplemented with further factors, especially for offence types which might have discernibly different characteristics such as violent or sex offences. Further research in this area could also engage with service users who might offer completely different accounts of the rehabilitation process such as members of ethnic or religious minorities or individuals with complex mental and emotional needs.

In the UK, further knowledge and assistance from other agencies could be incorporated within a ‘focused deterrence' model (Gill, 2016). Currently there exists an Integrated Offender Management Scheme to co-ordinate the management of offenders and rehabilitative programmes which might be of benefit (Gov.uk, 2015) but these seem only to consider the individual offender. There is scope to include insight from multiple agencies about how crime prevention or attentions in repeatedly victimised areas has been increased as might be the case within an American understanding of 'focused deterrence' (see Tillyer and Kennedy, 2008; Kennedy, 2009; Braga and Weisburd, 2012; Gill, 2016). A perception of increased risk by the offender could have a significant impact on the possibility of re-offending given the fundamental role this calculation played in participants' perceptions of their desistance. Of course, this study engaged only with individuals who had been complicit with their probation order (to the extent that they showed up to their probation centre and agreed to take part in 
this study) and so other methods are required as well to ascertain the perspectives of those who are less compliant. Furthermore, given the role illegal drug addiction plays in much acquisitive crime (Parker and Newcombe, 1987; Stewart et al. 2000; Holloway et al. 2004; Ceccato, 2009), the reflections of service users (Stacer and Roberts, 2018) and the accounts of the sample interviewed here, there is a need to highlight the importance of specialist drug and alcohol teams and their role in facilitating long-term desistance.

A significant finding to emerge from this study was, as one participant made clear, that the commission of vehicle crime requires a particular mind-set which continually perceives whether there is a possible opportunity to offend. What became clear from these accounts was that if focus is placed upon the impact of offending on victims and the unsustainability of repeated offending then criminal thinking can be resisted. As explored, the reasons why an individual might want to cease offending are numerous but one recurring theme was an element of shame or a lack of pride that committing offences seemed to engender. These reflections could be drawn upon during interactions with service users who are perhaps less inclined to cease offending but who have similar profiles or offending experiences. Subsequent work might also seek to explore service user satisfaction with the CRC and whether, after completing a probation license, they believed that supervision had been suitably tailored to their requirements to successfully desist. Remaining reflexive to the needs of service users is likely to offer the most effective platform for effective rehabilitation. In conclusion, it has been demonstrated that the former offender or service user provides a useful source for recognising factors that facilitate desistance and in future, knowledge of these reflections should help to provide suitable guidance to similar individuals. 


\section{References:}

Bennett, T., and Wright, R., (1984) Burglars on Burglary. Aldershot: Gower.

Braga, A. A., and Weisburd, D. L., (2012) The Effects of Focused Deterrence Strategies on Crime: A Systematic Review and Meta-Analysis of the Empirical Evidence. Journal of Research in Crime and Delinquency, 49 (3) 323-358.

Braithwaite, J., (1989) Crime, shame and reintegration. Cambridge: Cambridge University Press.

Brookman, F., (2011) Beyond the interview: complementing and validating accounts of incarcerated violent offenders. In. Bernasco, W., (eds.) Offenders on Offending: Learning about crime from criminals. Oxon: Routledge. Chapter 6.

Bryman, A., (2016) Social Research Methods, $5^{\text {th }}$ Edition. Oxford: Oxford University Press.

Ceccato, V., (2009) Crime in a City in Transition: The Case of Tallinn, Estonia, Urban Studies, Urban Studies, 46 (8) 1611-1638.

Chantler, A. N., (1995) Risk: The Profile of the Computer Hacker. Curtin University.

Cornish, D. B., and Clarke, R. V., (2014) The Reasoning Criminal: Rational Choice Perspectives on Offending. New Jersey: Transaction Publishers.

Crank, B. R., (2018) Accepting deviant identities: the impact of self-labeling on intentions to desist from crime, Journal of Crime and Justice, 41 (2) 155-172.

DLNR CRC., (2014a) Peer Mentoring (online) Available at: https://dlnrcrc.co.uk/reducingre-offending/peer-mentoring/ [Accessed 01.09.17]

DLNRC CRC., (2014b) About the CRC (online) Available at: https://dlnrcrc.co.uk/about-thecrc/ [Accessed 01.09.17] 
Ekblom, P., (1995) Less Crime, by Design. The Annals of the American Academy of Political and Social Science, 539 (1) 114-129.

Ekblom, P., (1997) Gearing Up Against Crime: a dynamic framework to help designers keep up with the adaptive criminal in a changing world, International Journal of Risk, Security and Crime Prevention, 2 (4) 249-265.

Elffers, H., (2011) Misinformation, misunderstanding and misleading as validity threats to offenders' accounts of offending. In. Bernasco, W., (eds.) Offenders on Offending: Learning about crime from criminals. Oxon: Routledge. Chapter 2.

Farrall, S., (2002) Rethinking What Works with Offenders: Probation, Social Context and Desistance from Crime. Cullompton: Willan Publishing.

Farrall, S., (2016) The Termination of Criminal Careers. London: Routledge.

Farrell, G., Tseloni, A., Mailley, J., and Tilley, N., (2011) The Crime Drop and the Security Hypothesis, Journal of Research in Crime and Delinquency, 48 (2) 147-175.

FBI: UCR., (2010a) Motor Vehicle Theft. (online) Available at: https://ucr.fbi.gov/crime-inthe-u.s/2010/crime-in-the-u.s.-2010/property-crime/mvtheftmain [Accessed 02.04.18].

FBI: UCR., (2010b) Larceny-theft. (online) Available at: https://ucr.fbi.gov/crime-in-theu.s/2010/crime-in-the-u.s.-2010/property-crime/larcenytheftmain [Accessed 02.04.18].

Felson, M., and Boba, R., (2010) Crime and Everyday Life. $4^{\text {th }}$ Edition. Thousand Oaks: Sage.

Gill, C., (2016) Community Interventions. In. Weisburd, D., Farrington, D. P., and Gill, C., (eds) What Works in Crime Prevention and Rehabilitation: Lessons from Systematic Reviews, New York: Springer. Chapter 3. 
Gill, M., (2017) Learning from Offenders: Some Iatrogenic Effect of Crime Prevention Measures, In. Leclerc, B., and Savona, E. U., (eds) Crime Prevention in the $21^{\text {st }}$ Century, Switzerland: Springer. Chapter 4.

Gottfredson, M. R., and Hirschi, T. (1990) A General Theory of Crime. Stanford: Stanford University Press.

Gov.uk., (nd) National Offender Management Service: About us (online) Available at: https://www.gov.uk/government/organisations/national-offender-managementservice/about\#how-we-work [Accessed 02.04.18].

Gov.uk., (2015) Integrated Offender Management. (online) Available at: https://www.gov.uk/guidance/integrated-offender-management-iom [Accessed 02.04.18].

Gov.uk., (2017) Vehicle Offences, (online) Available at:

https://www.gov.uk/government/uploads/system/uploads/attachment_data/file/602805/countvehicle-apr-2017.pdf [Accessed 01.09.17].

Hepburn, J. R., and Griffin, M. L., (2004) The Effect of Social Bonds on Successful Adjustment to Probation: An Event History Analysis, Criminal Justice Review, 29 (1) 46-75.

Hirschi, T., and Gottfredson, M. R., (2017) The Generality of Deviance. Oxon: Routledge.

Holloway, K., Bennett, T., and Lower, C., (2004) Trends in drug use and offending: the results of the NEW-ADAM Programme 1999-2002. London: Home Office.

Home Office., (2018) Home Office Counting Rules for Recorded Crime: Vehicle Offences. (online) Available at: https://assets.publishing.service.gov.uk/government/uploads/system/uploads/attachment_data /file/694441/count-vehicle-apr-2018.pdf [Accessed 02.04.18].

Hopkins, M., and Wickson, J., (2012) Targeting prolific and other priority offenders and promoting pathways to desistance: Some reflections on the PPO programme using a theory of change framework, Criminology and Criminal Justice, 13 (5) 594-614. 
Hughes, W., (2017) Lessons from the Integrated Domestic Abuse Programme, for the implementation of Building Better Relationships, Probation Journal, 64 (2) 129-145.

Hutchings, A., (2014) Crime from the keyboard: organised cybercrime, co-offending, initiation and knowledge transmission, Crime, Law and Social Change, 62 (1) 1-20.

Jacques, S., and Bonomo, E., (2017) Learning from the Offender's Perspective on Crime Prevention. In: Leclerc, B., and Savona, E. U., (eds.). Crime Prevention in the $21^{\text {st }}$ Century. Chapter 2. Switzerland: Springer International Publishing.

Justice., (2017) Offender Behaviour Programmes (OBPs). (online) Available at: https://www.justice.gov.uk/offenders/before-after-release/obp [Accessed 02.04.18].

Kay, C., (2016) Good cop, bad cop, both? Examining the implications of risk based allocation on the desistance narratives of intensive probationers, Probation Journal, 63 (2) 162-168.

Kennedy, D., (2009) Deterrence and Crime Prevention. London: Routledge.

King, S., (2013) Assisted desistance and experiences of probation supervision. Probation Journal, 60 (2) 136-151.

Lewis, S., (2006) Minority ethnic experiences of probation supervision and programmes. In. Lewis, S., Raynor, P., Smith, D., Wardak, A., (eds.) Race and Probation. Cullompton: Willan Publishing. Chapter 10.

Loughborough University., (nd) Ethics Approvals (Human Participants) Sub-Committee. (online) Available at:

http://www.lboro.ac.uk/media/wwwlboroacuk/content/universitycommittees/ethicsapprovalsh umanparticipantssub-committee/Data\%20Collection\%20and\%20Storage.pdf [Accessed 01.09.16]

Maguire, M., and Bennett, T., (1982) Burglary in a Dwelling: The Offence, the offender and the victim. London: Heinemann. 
Maruna, S. and Farrall, S., (2004) Desistance from crime: a theoretical reformulation, Kölner Zeitschrift für Soziologie und Sozialpsychologie, 43, 171-194.

Meyer, G. R., (1989) The Social Organization of the Computer Underground. Northern Illinois University.

National Audit Office (2007) Theft From Motor Vehicles: Identifying Potential Offenders. London: National Audit Office.

Nee, C., and Taylor, M., (2000) 'Examining burglars' target selection: interview, experiment, or ethnomethodology?', Psychology, Crime and Law, 6 (1) 45-59.

Nee, C., and Meenaghan, A. (2006) Expert Decision Making In Burglars, British Journal of Criminology, 46, 935-949.

Nee, C., (2011) Research on residential burglary: ways of improving validity and participants' recall when gathering data. In. W. Bernasco. (eds.) Offenders on Offending: learning about crime from criminals. Oxon: Routledge. Chapter 13.

Noaks, L., and Wincup, E., (2004) Criminological Research: Understanding Qualitative Methods. London: Sage Publications.

ONS., (2017) Crime in England and Wales: year ending June 2017. (online) Available at: https://www.ons.gov.uk/peoplepopulationandcommunity/crimeandjustice/bulletins/crimeinen glandandwales/june2017\#overview-of-crime [Accessed 02.04.18]

Parker, H., and Newcombe, R., (1987) Heroin Use and Acquisitive Crime in an English Community, The British Journal of Sociology, 38 (3) 331 - 350.

Paternoster, R., (1989) 'Decisions to Participate in and Desist from Four Types of Common Delinquency: Deterrence and the Rational Choice Perspective’, In. Farrall, S., (eds.) The Termination of Criminal Careers. London: Routledge. 
Polišenská, V. A., (2010) Interviewing offenders in a penitentiary environment and the use of mental maps during interviews. In. Bernasco, W., (eds.) Offenders on Offending. Oxon: Routledge. Chapter 15.

Quinn, A., and Grove, L., (2018) 'the whole window just shatters into a million pieces and it doesn’t make any sound': an examination of 'affordance' and situational cues for theft from a motor vehicle, Security Journal, https://doi.org/10.1057/s41284-018-0136-3

Ratcliffe, J. H., (2009) Strategic Thinking in Criminal Intelligence, $2^{\text {nd }}$ Edition. Sydney: The Federation Press.

Ritchie, J., Lewis, J., Mcnaughton-Nicholls, C., Ormston, R., (2014) Qualitative Research Practice. London: Sage.

Shover, N., (1973) The Social Organization of Burglary, Social Problems, 20: 499-514.

Shover, N., and Thompson, C. Y., (1992) Age, Differential Expectations, and Crime Desistance, In. Farrall, S., (eds.) The Termination of Criminal Careers. London: Routledge. Chapter 18.

Stacer, M. J., and Roberts, M. R., (2018) “'Reversing the trend”: The role of mentoring in offender re-entry, Journal of Offender Rehabilitation, 57 (1) 1-21.

Stewart, D., Gossop, M., Marsden, J., and Rolfe, A., (2000) Drug misuse and acquisitive crime among clients recruited to the National Treatment Outcome Research Study (NTORS), 10 (1) 10-20.

- Stoneman, M., Jackson, L., Dunnett, S., and Cooke, L., (2018) Variation in detainee risk assessment within police custody across England and Wales, Policing and Society, https://doi.org/10.1080/10439463.2018.1467906

The DLNR CRC., (2014) About the CRC (online) Available at: https://dlnrcrc.co.uk/aboutthe-crc/ [Accessed 02.04.18]. 
Tilley, N., Farrell, G., Clarke, R. V., (2015) Target Suitability and the Crime Drop. In. Andresen, M., and Farrell, G., (eds.) The Criminal Act: The Role and Influence of Routine and Activity Theory. Basingstoke: Palgrave Macmillan. Chapter 5.

Tillyer, M. S., and Kennedy, (2008) Locating Focused Deterrence Approaches within a Situational Crime Prevention Framework. Crime Prevention and Community Safety, 10 (2) 75-84.

Walsh, D., (1986) Heavy Business: Commercial Burglary and Robbery. London: Routledge.

Weaver, B., and McNeil, F., (2011) Travelling hopefully: desistance theory and probation practice, In Brayford, J., Cowe, F., and Deering, J., (eds.) What else works? Creative work with offenders. Oxon: Routledge. Chapter 3.

Weerman, F. M., (2003) Co-offending as Social Exchange. Explaining Characteristics of Cooffending, The British Journal of Criminology, 43 (2) 398-416.

Weisburd, D., Eck, J. E., Braga, A. A., Telep, C. W., Cave, B., Bowers, K., Bruinsma, G., Gill, C., Groff, E. R., Hibdon, J., Hinkle, J. C., Johnson, S. D., Lawton, B., Lum, C., Ratcliffe J. H., Rengert, G., Taniguchi, T., Yang, S., (2016) Place Matters: Criminology For The Twenty-First Century. Cambridge: Cambridge University Press.

Williams, P., (2006) Designing and delivering programmes for minority ethnic offenders. In. Lewis, S., Raynor, P., Smith, D., Wardak, A., (eds.) Race and Probation. Cullompton: Willan Publishing. Chapter 8. 